Synthesis and study silver nanoparticles by chemical method

Ali L. Abed

\title{
Synthesis and study silver nanoparticles by chemical method
}

\begin{abstract}
Ali L. Abed
Nanotechnology advanced material research center- University of Technology- Baghdad-Iraq
\end{abstract}

Received: 23 March $2016 \quad$ Accepted: 5 May 2016

\begin{abstract}
$\underline{\text { Abstract }}$
In this paper, Ag nanoparticles with various sizes and forms are made by using reduction methods of Ag ions in aqueous solutions in the presence of strong reducing agents like hydrogen peroxide $\left(\mathrm{NaBH}_{4}\right)$ with different concentrations of silver nitrate $\mathrm{AgNO}_{3}(1 \mathrm{mM}$ to $0.9 \mathrm{mM})$ improving its effect on the stability of the nanoparticles. From the results, stability of the Ag nanoparticles is due to the ions of $\mathrm{NaBH}_{4}$ that surrounding the nanoparticles and decreased from aggregating as demonstrated by using UV-VIS spectra, Particle size analyzer (PSA), Scanning Electron Microscopy (SEM) and Transmission Electron Microscopy (TEM) to determine their behavior as catalyst materials and analysis the kinetics of reactions.
\end{abstract}

Keywords: Silver Nanoparticle (AgNPs), stability of the nanoparticles, strong reducing agent, chemical method

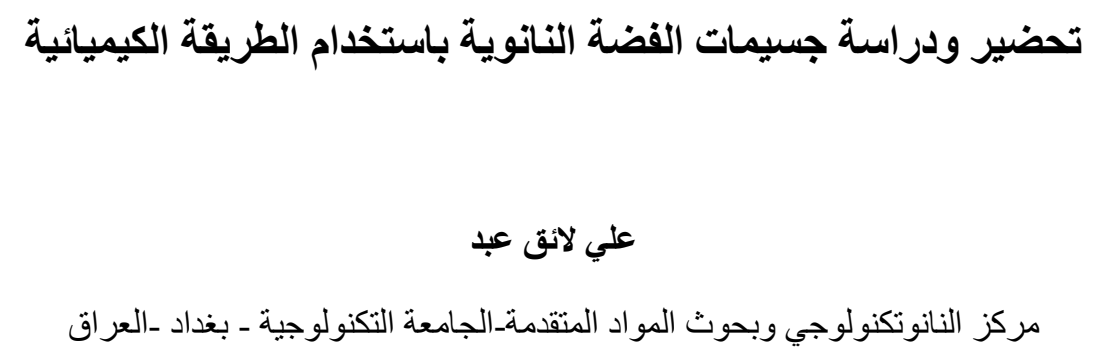




\section{Synthesis and study silver nanoparticles by chemical method}

Ali L. Abed

\section{الخلاصة}

في هذا العمل، تم تحضير جسيمات الفضة النانوية باحجام واشكال مختلفة باستخدام الطريقة الكيميائية المختزلة لايونات الفضة في المحاليل المائية بوجود عامل مختزل قوي مثل بيروكسي الهيدروجين NaBH4 بتر اكيز مختلفة من نترات الفضة

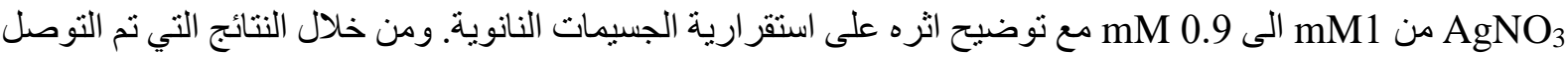
اليها فان استقر اية جسيمات الفضة تعود الى دور ايونات بيروكسي الهيدروجين في احاطة الجسيمات النانوية ومنع التجمعات كما هو ملاحظ في مطياف الاشعة فوق البنفجي UV-VIS وفحص محلل الجسيمات PSA و جهاز الماسح الالكتروني بالاضافة الى جهاز النافذ الالكتروني TEM لغرض در اسة الفعل التحفيزي للعامل المختزل في حركية التفاعل الكلمات المفتاحية:جسيمات الفضة النانوية،استقر اية الجسيمات النانوية، عامل الاختزال القوي ،الطريقة الكيميائية

\section{Introduction}

nanomaterials have received considerable consideration with the recognition of their dramatically altered material properties as compared to their bulk materials. As a result, the nanoparticles have wide applications in civil and manufacturing fields. For example, they are used as micro-electronic materials, bactericidal materials, catalyst materials and Magnetic materials of Recording. Also, they have possible applications in detection of DNA and photodetection [1]. The change of bulk material to nanomaterials results in distinctive features that are controlled by two main issues. First issue represented by decreasing in size of the particles, while the second issue including the number of atoms at the surface is increases noticeably as compared with the number of atoms in the center of the crystal and the broadly nanomaterials using is silver nanoparticles (AgNPs) [2]. Silver nanoparticles have attracted considerable interest because of their size and shape properties like optical, electrical, and magnetic properties beside to possible applications in a common of fields including plasmon, nanoelectronics, chemical sensing and composite materials, cosmetic products, and electronic components. So far, many Ag nanostructures have been successfully synthesized with various morphologies [3-5].Silver nanoparticles with different shapes, sizes and surface properties are created using a variety of methods because of the type of reducing and capping agents used to prevent their aggregation [6]. Silver nanoparticles are often created by using silver nitrate dissolving in Distill Water (DW) with $\mathrm{NaBH} 4$ or citrate as reducing agents or as capping agents resulting mostly in negatively charged surfaces [7]. In the past, a number of processes are used 
Synthesis and study silver nanoparticles by chemical method

Ali L. Abed

to form silver nanoparticles, consist of reduction method of $\mathrm{Ag}$ ions in aqueous solvent with or without surfactants, electro-chemical reduction, heat evaporation, thermal decomposition in aqueous solvents, as well as poly procedure like chemical and photo-reduction, and radiation chemical reduction. All these procedures of synthesis include reduction of noble metals in the presence or absence of surfactants that is essential in control the formation of metal colloids during agglomeration [8-10]. The synthesis of silver nanoparticles is well documented and usually, the nanoparticles are obtained by bottom-up methods where atoms are self-assembly into nanoparticles [11]. Therefore, chemical reduction route has been intensively used and many reducing agents have been tested such as trisodium citrate [12], ethylene glycol [13], or sodium borohydride [14]. Besides, solution temperature, concentrations of the metal salt, reducing agent and reaction time also control particle size. Since, controlling size and shape of metal nanoparticles remains a challenge [15]. This study concerns the formation of silver nanoparticles using chemical reduction reaction by changing the concentration of $\mathrm{AgNO}_{3}$ from $1 \mathrm{mM}$ to $0.9 \mathrm{mM}$ while the concentration of $\mathrm{NaBH} 4$ which is a strong reducing agent is kept constant. Then, the micrograph and average particle size of the Silver nanoparticles obtained from each sample was observed by Scanning Electron Microscope (SEM), Transmission Electron Microscopy (TEM) and Particle size analyzer (PSA). The absorbance of solution containing Ag nanoparticles was measured using UV -Vis absorption spectroscopy at room temperature in the wavelength ranging from 300 to $900 \mathrm{~nm}$ improving Ag nanoparticles stability with changing the $\mathrm{AgNO}_{3}$ concentration and keeping the concentration of reducing agent constant.

\section{$\underline{\text { Experimental procedures }}$}

Preparation silver nanoparticles (AgNPs) using various concentrations of $\mathrm{AgNO}_{3}$ and its effect on sodium borohydride as strong reducing agent

The synthesis of Ag nanoparticles, using reduction reaction, involved the reduction of AgNO3 by strong reducing agents such as $\mathrm{NaBH}_{4}$. In the first approach, a colloidal of $2 \mathrm{mM} \mathrm{NaBH}_{4}$ is formed by dissolving $0.0079 \mathrm{~g}$ of $\mathrm{NaBH}_{4}$ in $100 \mathrm{~mL}$ of Distill Water (DW) and $1 \mathrm{mM} \mathrm{AgNO} 3$ is formed dissolving $0.019 \mathrm{~g}$ of $\mathrm{AgNO} 3$ in new baker of $100 \mathrm{~mL}$ of Distill Water (DW). Then 


\section{Synthesis and study silver nanoparticles by chemical method}

Ali L. Abed

the solutions are mixed collectively by adding $5.0 \mathrm{~mL}$ of $1 \mathrm{mM} \mathrm{AgNO} 3$ drop-wise about 2 minutes to $30 \mathrm{~mL}$ of cold $2.0 \mathrm{mM} \mathrm{NaBH}_{4}$. The forming solution is regularly stirred. Then 5 minutes later, a yellow color colloidal of Ag nanoparticles is achieved. In the second approach of formation Ag nanoparticles, the concentration of $\mathrm{AgNO} 3$ is changed by decreasing to 0.90 $\mathrm{mM}$, but the concentration of $\mathrm{NaBH}_{4}$ used is kept. A colloidal of $\mathrm{AgNO}_{3}$ is prepared dissolving $0.017 \mathrm{~g}$ of $\mathrm{AgNO}_{3}$ in $100 \mathrm{~mL}$ of Distill Water (DW). Then $10 \mathrm{~mL}$ of $0.9 \mathrm{mM} \mathrm{AgNO}$ is added to $30 \mathrm{~mL}$ of $2 \mathrm{mM}$ cold $\mathrm{NaBH}_{4}$. After 5 minutes with stable stirred, Ag nanoparticles of a darker yellow colloidal is formed.

\section{Characterization of prepared AgNPs}

The synthesis of Ag nanoparticles is characterized by UV- Vis spectral analysis (SP8001, Metertech) and Particle size analyzer (PSA, NanoBrook 90Plus Particle Size Analyzer) to predict the size of the Ag nanoparticle and their stability. Scanning Electron Microscopy (SEM) was performed for studying the surface morphology and structure of silver nanoparticles and Transmission Electron Microscopy (TEM, EM208, Philips, Day Petronic Co., Tehran, Iran) to demonstrate the typical shape and size of AgNPs.

\section{$\underline{\text { Results and Discussion }}$}

\section{UV-VIS spectra}

Ag nanoparticles of different types were characterized by UV/Vis spectroscopy, as their Surface Plasmon Resonances (SPR) cause different peaks in their absorption spectra. The absorbance of $\mathrm{UV}-\mathrm{Vis}$ spectra for various concentrations $\mathrm{AgNO}_{3}$ aqueous solution with reducing agents like sodium borohydride, is shown in Fig 1. For the first approach, UV-visible absorption spectra shows a maximum of absorption peak at $407 \mathrm{~nm}$ with the average particle size from 25 to $200 \mathrm{~nm}$ with small spherical shapes when the concentration sodium borohydride $2 \mathrm{mM}$ and $\mathrm{AgNO}_{3} 1 \mathrm{mM}$, yellow silver nanoparticle solution was obtained which implies the effect of $\mathrm{NaBH}_{4}$ as reducing agent and its stability for more than one month. 
Synthesis and study silver nanoparticles by chemical method

Ali L. Abed

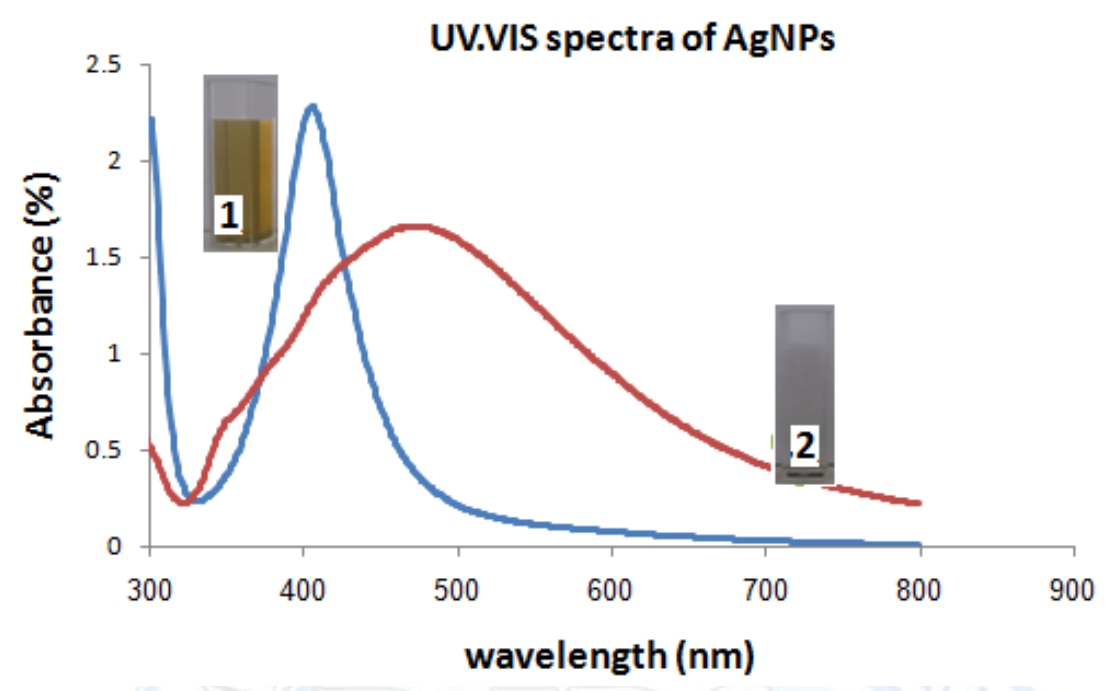

Fig 1: UV-Vis spectra of Ag nanostructures using a) $1 \mathrm{mM}$ of $\mathrm{AgNO}_{3}$ and b) $0.9 \mathrm{mM}$ of

$$
\mathrm{AgNO}_{3}
$$

Then, the absorbance of plasmon peak is shifted towards longer wavelength as the sizes increase, $473.25 \mathrm{~nm}$ with changing the concentration of $\mathrm{AgNO}_{3}$ from $1 \mathrm{mM}$ to $0.9 \mathrm{mM}$ that point to decompose or aggregate Ag nanoparticle solution and forming large spherical shapes with deep yellow color of the colloidal solution and one month as shown in Fig (1b) with average particle size greater than $50 \mathrm{~nm}$. 


\section{DIYALA JOURNAL FOR PURE SCIENCES}

Synthesis and study silver nanoparticles by chemical method

Ali L. Abed

SEM analysis
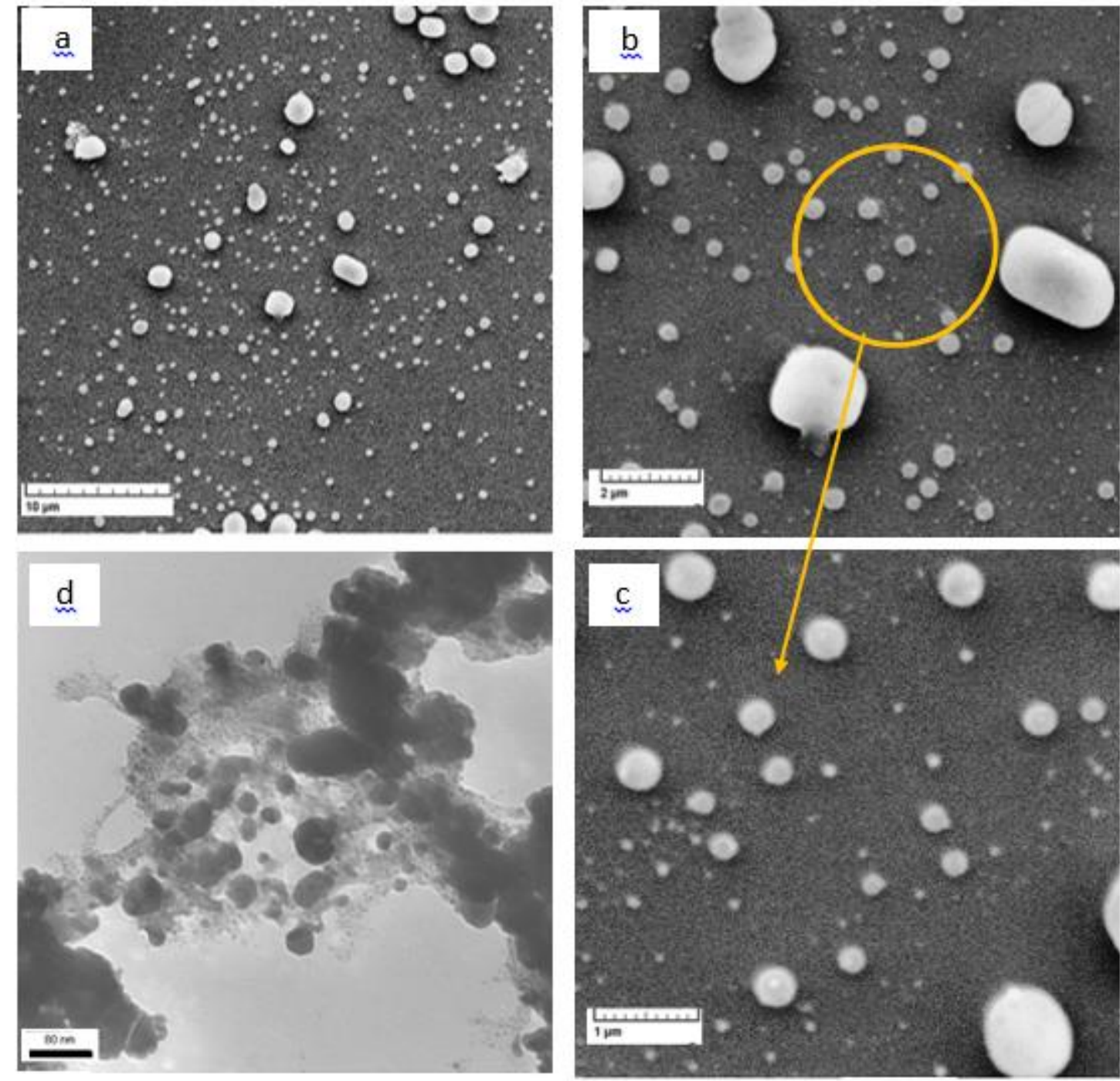

Fig 2: SEM micrograph of Ag NPs using $2 \mathrm{mM}$ of $\mathrm{NaBH} 4$ with $1 \mathrm{mM}$ of $\mathrm{AgNO}_{3}$ at different magnification a) $10 \mu \mathrm{m}$, b) $2 \mu \mathrm{m}, 1 \mu \mathrm{m}$ and d)TEM micrograph of Ag NPs with $1 \mathrm{mM}$ at magnification 80nm 
Synthesis and study silver nanoparticles by chemical method

Ali L. Abed

The SEM micrograph of the $\mathrm{Ag}$ nanoparticles formed by reduction $2 \mathrm{mM}$ of sodium borohydride with $1 \mathrm{Mm}$ of $\mathrm{AgNO}_{3}$ solution are shown in Fig (2 a,b,c). Small-sized and spherical Ag nanoparticles with average particle size from 25 to $200 \mathrm{~nm}$ are formed due to the borohydride method as shown in Fig (2 a,b,c). in addition to SEM analysis , Fig (2d), shows the TEM micrograph as high resolution to investigate in more detail the formation of spherical shape of Ag nanoparticles with average particle size range from 20-200nm which improved the role of $\mathrm{NaBH}_{4}$ in reaction with $\mathrm{AgNO}_{3} 1 \mathrm{mM}$. While Fig (3 a,b,c),indicates the existence of agglomerated nearly spherical shaped of Ag nanoparticles with average particle size greater than $50 \mathrm{~nm}$ when the concentrations of $\mathrm{AgNO}_{3}$ change from $1 \mathrm{mM}$ to $0.9 \mathrm{mM}$ while the concentration of sodium borohydride is kept constant which indicating the stability of silver nanoparticles is decreased and there is no reaction take place as improved by suing TEM micrograph as shown in Fig (3d), which reveals forming large size of AgNPs grater that 50nm. Since, the reduction of Ag ions is not complete because of the concentration of $\mathrm{NaBH}_{4}$ was becoming more excessive $(2 \mathrm{mM})$ than the concentration of $\mathrm{AgNO}_{3}(0.9 \mathrm{mM})$. Since a small particles begin to aggregate into large particles as deals with our results in UV-visible absorption spectra. 


\section{DIYALA JOURNAL FOR PURE SCIENCES}

Synthesis and study silver nanoparticles by chemical method

Ali L. Abed
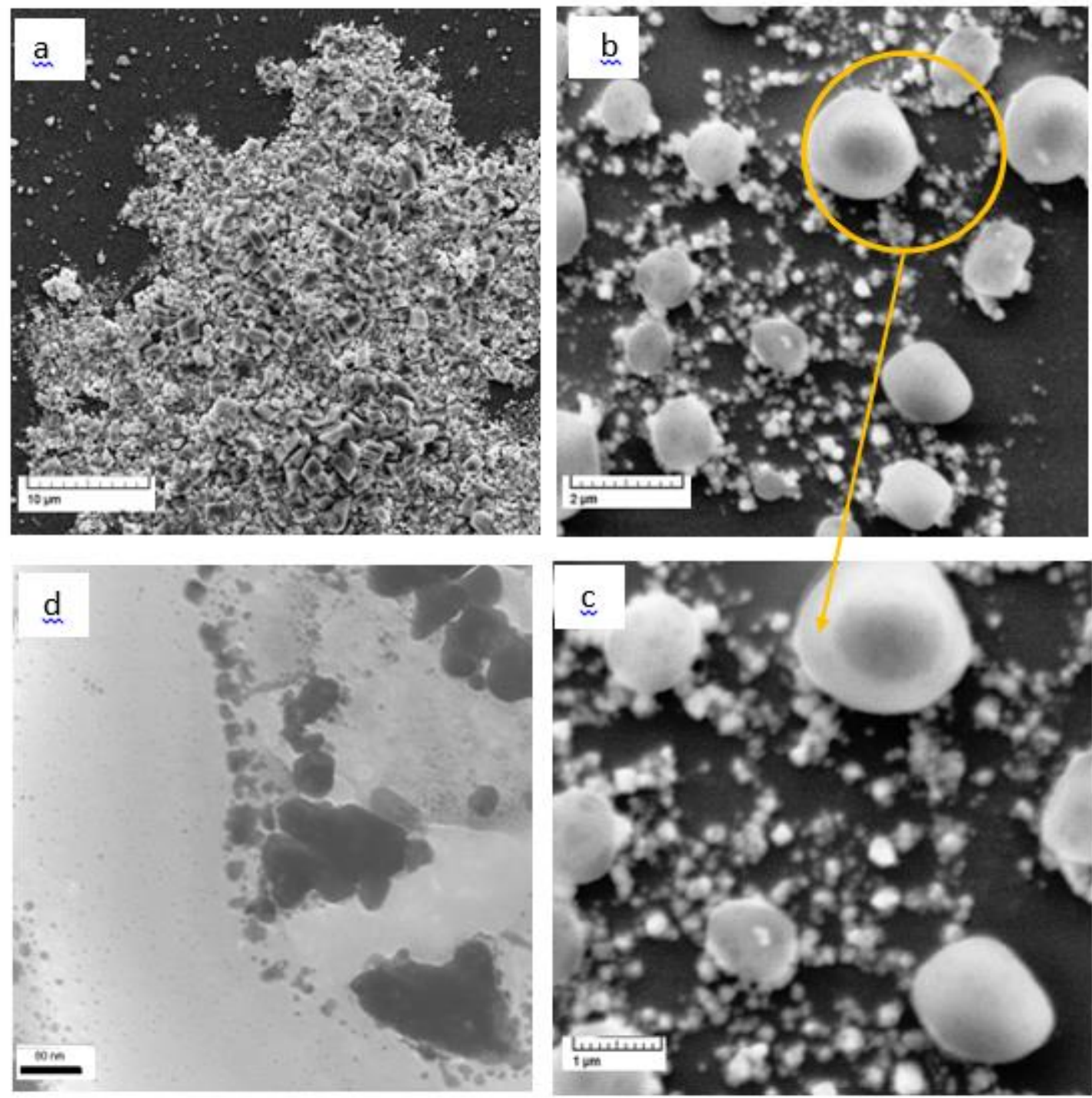

Fig 3: SEM micrographs of silver nanostructures using $2 \mathrm{mM}$ of $\mathrm{NaBH}_{4}$ with $0.9 \mathrm{mM}$ of $\mathrm{AgNO}_{3}$ at different magnification a)10 $\left.\mu \mathrm{m}, \mathrm{b}\right) 2 \mu \mathrm{m}$ and $1 \mu \mathrm{m} \mathrm{d}$ )TEM micrograph of $\mathrm{Ag}$ NPs with $0.9 \mathrm{mM}$ at magnification $80 \mathrm{~nm}$ 
Synthesis and study silver nanoparticles by chemical method

Ali L. Abed

\section{The Particle Analyzer test}

Particle Size Analysis (PSA) of Ag nanoparticles as illustrated in Fig (4 a), represents the Particles diameter range in size from 5 to $5000 \mathrm{~nm}$ with average diameter $12.55 \mathrm{~nm}$ when the concentrations of $\mathrm{AgNO}_{3}$ was about $1 \mathrm{mM}$ which represent the formation a few but large $\mathrm{Ag}$ nanoparticles in $1 \mathrm{mM} \mathrm{AgNO} 3$ reduction with $2 \mathrm{mM} \mathrm{NaBH}_{4}$.
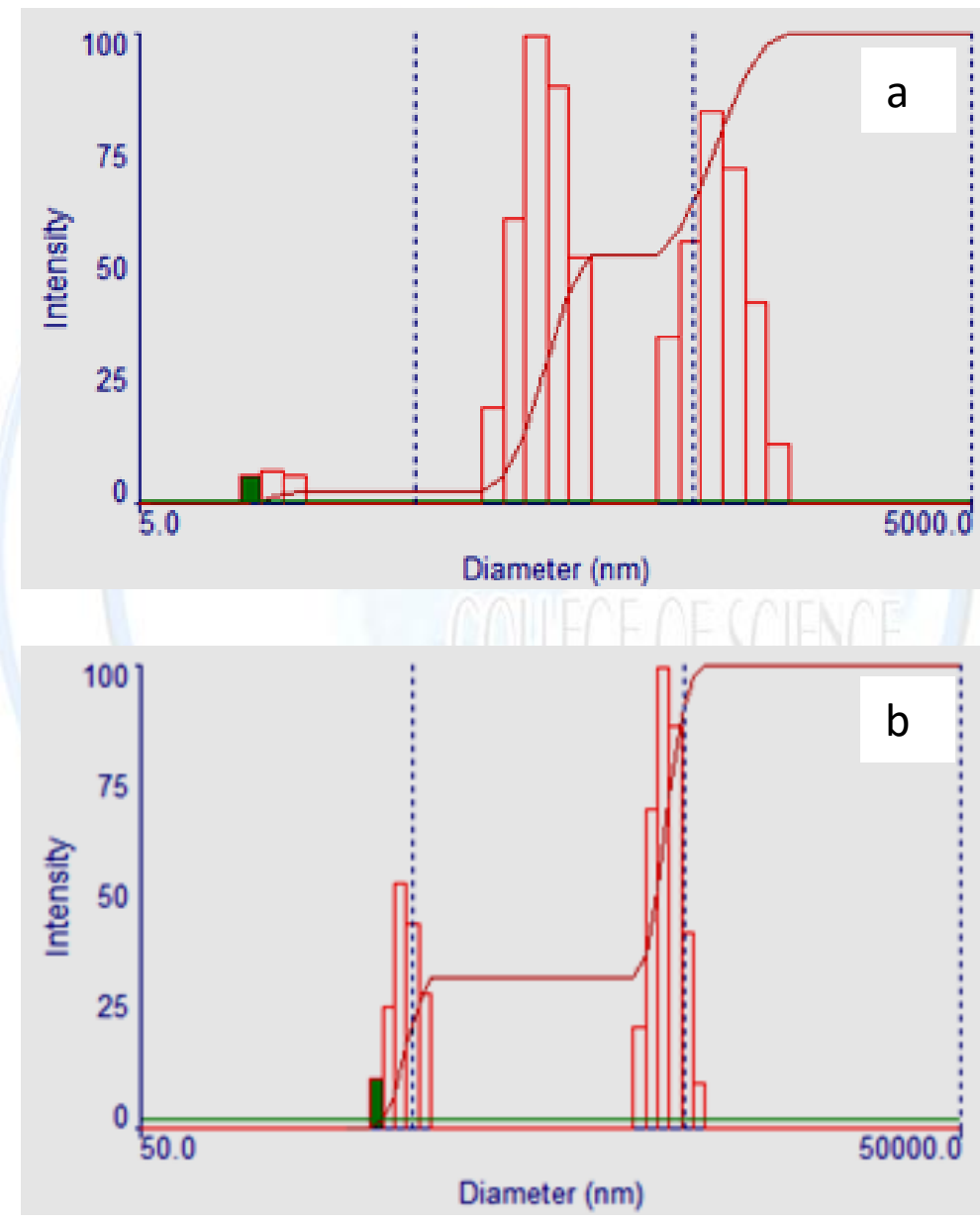

Fig 4: Particle Size of the Ag nanoparticles formation using $2 \mathrm{mM}$ of $\mathrm{NaBH}_{4}$ with a) $1 \mathrm{mM}$ of $\mathrm{AgNO}_{3}$ and b) $0.9 \mathrm{mM}$ of $\mathrm{AgNO}_{3}$ 
Synthesis and study silver nanoparticles by chemical method

Ali L. Abed

In Fig (4 b), the particle size analysis (PSA) shows silver nanoparticles diameter range from 50 to $50000 \mathrm{~nm}$ with mean diameter $366 \mathrm{~nm}$ when the concentrations of $\mathrm{AgNO}_{3}$ is decreased to $0.9 \mathrm{mM}$ as compared to $\mathrm{NaBH}_{4}$ concentrations $2 \mathrm{mM}$ and leads to reduction of $\mathrm{Ag}$ ions was not complete which results in aggregation of particles producing and a great quantity of $\mathrm{Ag}$ nanoclusters while a few quantity of nanoparticles were produced.

\section{Conclusions}

In summary, the results indicate that the particle size can be ranged from small size to bigger size depending on the concentration of reducing agent and $\mathrm{AgNO}_{3}$ which is a limiting feature in Ag nanoparticles stability. In addition, the stability of Ag nanoparticles results from the fact that $\mathrm{Ag}$ nanoparticles created from $\mathrm{NaBH}_{4}$ ions are surrounding the nanoparticles and preventing them from agglomerates while the excessive $\mathrm{NaBH}_{4}$ concentration leads to prevent the reduction of $\mathrm{Ag}$ ions which results in aggregation of the particles and a large amount of $\mathrm{Ag}$ nanoclusters are formed as improved in UV. Vis, SEM, TEM and particle size analysis (PSA).

\section{Acknowledgements}

Author gratefully acknowledges center of nanotechnology and advanced material research, Technology University, Baghdad, Iraq for carrying out the SEM (VEGA Easy Probe), UV- Vis spectral analysis (SP8001, Metertech) and Particle size analyzer (PSA, NanoBrook 90 Plus Particle Size Analyzer) and TEM (EM208, Philips, Day Petronic Co., Tehran, Iran) for their help and support. 


\section{Synthesis and study silver nanoparticles by chemical method}

Ali L. Abed

\section{References}

1. W. Zhang, X. Qiao, J. Chen," Synthesis of silver nanoparticles Effects of concerned parameters in water/oil microemulsion", Colloids Surf. A, 299, PP.22-28,(2007).

2. Nanoparticles: from theory to application, edited by Gunter Schmid, Wiley-VCHVerlag Gmbhand Co.KGaA, (2004).

3. X. Liu, F. Zhang, R. Huang, C. Pan, and J. Zhu," Capping Modes in PVP-Directed Silver Nanocrystal Growth: Multi-Twinned Nanorods versus Single-Crystalline NanoHexapods",Crystal Growth \& Design, Vol. 8, No. 6, PP.1916-1923,(2008)

4. A. Shukla, B. A. Makwana,"Facile Synthesis of Ag Nanoparticle and Their potential application", Am. J. of Nanscl. Nanotech, Vol. 2, PP. 84-92,(2014)

5. M. G. Guzmn, J. Dille, S. Godet," Synthesis of silver nanoparticles by chemical reduction method and their antibacterial activity",Inter. Journal of Chemic. and Biological Engineering Vol. 2,No.3,PP.104-111,(2009).

6. H. Kishan Sodha, K. Jaymin Jadav, P. Harsukh Gajera, J. Khyati Rathod," Characterization of Silver Nanoparticles Synthesized By different chemical reduction methods", Int. J. Pharm Bio Sci , Vol.6, No.4 ,PP. 199 -208,( 2015)

7. T. M. Tolaymat, A. M. El Badawy, A. Genaidy, K. G. Scheckel, T. P. Luxton, M. Suidan, "An evidence-based environmental perspective of manufactured silver nanoparticle in syntheses and applications", Sci. Total Environ., 408,PP.999-1006,(2010).

8. A. Abdalrahim,"Preparation and Characterization of Silver Nanoparticles", International Journal of Chem.Tech. Research, Vol.6, No.1, pp 450-459,(2014).

9. M. Z. Rafiquee, M. R. Siddiqui, H. A. Al-Lohedan, Z. A. Al-Othman,"Synthesis, characterization and kinetics of formation of silver nanoparticles by reduction with adrenaline in the micellar media", Bioprocess Biosyst Eng. Vol.38, No.4, PP.711-9,(2015)

10. P. Van Dong, C. Hoang Ha, L. Tran Binh , Jörn Kasbohm," Chemical synthesis and antibacterial activity of novel-shaped silver nanoparticles",Int. Nano Letters „PP. 2$9,(2012)$.

11. K. Tan, K. Cheong,"Advances of $\mathrm{Ag}, \mathrm{Cu}$, and $\mathrm{Ag}-\mathrm{Cu}$ alloy nanoparticles synthesized via chemical reduction route", Journal of Nanoparticle Research, 15,PP. 1-29, (2013). 
Synthesis and study silver nanoparticles by chemical method

Ali L. Abed

12. X. Qiu Xiliang,Y. Cao,T. Lin,P. He, J. Wang, and X. Gu,"Large-Scale Synthesis of Silver Nanoparticles by Aqueous Reduction for Low-Temperature Sintering Bonding", Journal of Nanomaterials ،Vol. 2014, No. 1 P.8, (2014)

13. Y. Akada, H. Tatsumi, T. Yamaguchi, A. Hirose, T. Morita, E. Ide, "Interfacial bonding mechanism using silver metallo-organic nanoparticles to bulk metals and observation of sintering behavior", Materials Transactions, 49 ,PP.1537-1545, (2008).

14. M. Liu, M. Leng, C. Yu, X. Wang, and C. Wang,"Selective Synthesis of Hexagonal Ag Nanoplates in a Solution-Phase chemical reduction Process", Nano Res., Vol. 3,No.12PP. 843-851, (2010)

15. S. Budi Harmami, D. Sondari, A. Haryono," The Synthesis of Silver Nanoparticles Produced by Chemical Reduction of Silver Salt Solution", Indonesian Journal of Materials, 233, (2008) 